\title{
Optimasi Uji Difusi Kombinasi Testosteron Undekanoat (TU) dan Medroksi Progesteron Asetat (MPA) dalam Sediaan Mikroemulsi
}

\section{Azrifitria, Supandi dan Muhardi Ritonga}

Program Studi Farmasi, Fakultas Kedokteran dan Ilmu Kesehatan, UIN Syarif Hidayatullah, Jakarta

Korespondensi: Azrifitria

Email: azrifitria72@gmail.com

\begin{abstract}
ABSTRAK: Uji difusi kombinasi testosteron undekanoat (TU) dan medroksi progesteron asetat (MPA) dalam sediaan mikroemulsi yang telah dilakukan belum menunjukkan profil difusi yang optimal. Penelitian ini bertujuan untuk mengoptimasi medium difusi dan kinetika pelepasan sediaan mikroemulsi TU dan MPA. Parameter yang dioptimasi dalam penelitian ini adalah medium difusi yaitu menggunakan medium $\mathrm{NaCl}$ fisiologis, phosphate buffer saline (PBS) dan isopropanol-air (1:9). Pengujian difusi dilakukan dengan menggunakan alat Franz Diffusion Cell dan otot paha tikus jantan Sprague-Dawley sebagai membran difusi yang dilakukan selama 18 jam. Hasil uji difusi dianalisis dengan kromatografi cair kinerja tinggi (KCKT) pada kondisi optimum dengan fase gerak metanolasetonitril (90:10), kolom $\mathrm{C}_{18}$, laju alir 1,2 ml/menit, volume injeksi $20 \mu$ dan menggunakan detektor UV-Vis pada panjang gelombang $243 \mathrm{~nm}$. Hasil analisis menunjukkan medium difusi yang paling optimum adalah isopropanol-air (1:9). Kinetika pelepasan sediaan tersebut mengikuti kinetika orde nol dengan nilai $r=0,9913$ untuk TU dan nilai $r=0,9777$ untuk MPA.
\end{abstract}

Kata kunci: mikroemulsi; TU; MPA; Franz Diffusion Cell; KCKT

\begin{abstract}
Microemulsion diffusion test with a combination of the active substance testosterone undecanoate and medroksi progesterone acetate that has been done showed the diffusion profiles were not optimal. This study aims to optimize medium diffusion and kinetics of release of active substances TU and MPA in the microemulsion preparation. Optimized parameters were the diffusion medium using physiological saline medium, phosphate buffer saline (PBS) and isopropanol-water (1:9). Diffusion test were done by using a Franz Diffusion Cell and thigh muscle male Sprague-Dawley rats as diffusion membrane, the test was conducted for 18 hours. The results of diffusion test were analyzed by High Performance Liquid Chromatography (HPLC) at the optimum mobile phase conditions methanol-acetonitrile (90:10), $C_{18}$ column, flow rate of $1.2 \mathrm{ml} / \mathrm{min}$, injection volume of $20 \mathrm{ml}$ and using UV-Vis detector at wavelength of 243 $\mathrm{nm}$. The analysis showed that the most optimum medium diffusion is isopropanol-water (1:9). The release kinetics of microemulsion followed zero-order kinetics with $r=0.9913$ for TU and $r=0.9777$ for the MPA.
\end{abstract}

Keywords: microemulsion; TU; MPA; Franz Diffusion Cell; HPLC 


\section{Pendahuluan}

Kombinasi testosteron undekanoat (TU) dan medroksi progesteron asetat (MPA) sedang dikembangkan sebagai kontrasepsi hormonal pada pria efektif dalam menginduksi spermatogenesis sehingga mencapai azoospermia [1]. Penggunaan TU dan MPA memiliki masa kerja yang panjang, sehingga mempunyai efek farmakokinetik dan farmakodinamik lebih baik dibandingkan dengan bahan lain, seperti kombinasi testosteron enantat (TE) dan MPA [2]. Sediaan TU dan MPA biasanya diberikan scara intra muskular dengan 2x penyuntikan sehingga menimbulkan rasa tidak nyaman, oleh karenanya dibuatlah suatu sedian mikroemulsi. Senyawa TU dan MPA bersifat lipofil dengan koefisien korelasi 6,91 dan 2,92 [3].

Sediaan mikroemulsi TU dan MPA dilakukan uji difusi, pengujian difusi merupakan pengujian dasar terhadap suatu sediaan obat. Difusi adalah suatu proses perpindahan massa molekul suatu zat yang dibawa oleh gerakan molekular secara acak dan berhubungan dengan adanya perbedaan konsentrasi aliran molekul melalui suatu batas [4]. Difusi mikroemulsi terjadi pada saat sediaan melepaskan senyawa obat ke dalam cairan tubuh untuk diabsorpsi. Penelitian ini bertujuan mengoptimasi medium difusi dan pengekstraksian TU dan MPA. Medium yang digunakan adalah $\mathrm{NaCl}$ fisiologis, phosphate buffer saline (PBS) dan isopropanol-air (1:9) serta dua larutan pengekstraksi kloroform dan pentana untuk mengetahui pelepasan kadar tertinggi dari TU dan MPA dalam sediaan mikroemulsi. Pengujian difusi dengan Franz Diffusion Cell yang terdiri dari dua kompartemen yaitu kompartemen donor dan kompartemen reseptor. Kedua kompartemen ini dipisahkan oleh barrier/ membran otot paha tikus sebagai studi in vitro dalam pengembangan sediaan baru.

\section{Metode}

\subsection{Alat}

Kromatografi cair kinerja tinggi (KCKT) $\left(\right.$ Dionex $^{\circledR}$, Germany) yang terdiri dari pompa ultimate 3000, kolom $\mathrm{C}_{18}(150 \mathrm{~mm}, 4,6 \mathrm{~mm} ; 5,0$ $\mu \mathrm{m})$, auto injector, detector UV-VIS dan software Chromeleon ver. 6,8 DU., seperangkat alat Franz Diffusion Cell, alat-alat gelas (Iwaki Pyrex ${ }^{\circledR}$ ), potongan melintang otot tikus, timbangan analitik (AND GH-202 ${ }^{\circledR}$ ), mikro pipet (Eppendorf), lemari pendingin (Sanyo Medicool ${ }^{\circledR}$ ), stirrer (Nuova Stirrer ${ }^{\circledR}$ ), serta hot plate (Wiggen Hauser ${ }^{\circledR}$ ).

\subsection{Bahan}

Testosterone undekanoat (Xianju Co Ptd., Cina), medroksi progesteron asetat (Badan POM, Jakarta), benzil benzoat, isopropil miristat, Tween 80, aquadest pro HPLC, asetonitril pro HPLC, methanol pro HPLC, natrium fosfat, natrium klorida, kalium hidroksida (Merck, Manheim, Germany), dan castor oil (Aldrich, Fisher Scietific, Ireland).

\subsection{Uji difusi}

Pengujian dilakukan dengan difusi vertikal Franz Diffusion Cell. Sebanyak $1 \mathrm{ml}$ sampel ditempatkan pada kompartemen donor. Larutan reseptor diaduk dengan magnetic stirrer untuk menjaga agar zat aktif tetap homogen dalam larutan medium. Temperatur pada saat pengujian diatur konstan pada suhu $37^{\circ} \mathrm{C}$ dengan menggunakan thermostat. Sebagai barrier digunakan potongan melintang otot tikus jantan. Untuk menciptakan kondisi sink, digunakan medium difusi sebanyak $23 \mathrm{ml}$. Medium yang digunakan adalah $\mathrm{NaCl}$ fisiologis, PBS dan isopropanol-air (1:9). Pada interval waktu yang telah ditentukan $(1,2,3,4,5,6,8,9,10,11$ hingga 18 jam), diambil cuplikan sebanyak $1 \mathrm{ml}$. Tiap pengambilan cuplikan, sejumlah cairan yang diambil digantikan dengan larutan fisiologis dengan volume yang sama. Penentuan kadar MPA dan TU pada sampel dilakukan dengan menggunakan metode KCKT.

\subsection{Preparasi sampel cuplikan uji difusi}

Cuplikan dari medium uji difusi diambil sebanyak $100 \mu \mathrm{l}$, dimasukkan ke dalam labu ukur $5 \mathrm{ml}$, kemudian ditambahkan larutan fase gerak 
hingga $5 \mathrm{ml}$. Diambil $500 \mu \mathrm{l}$ dimasukkan ke dalam vial HPLC. Hal yang sama dilakukan pada medium difusi lainnya.

\subsection{Penetapan kadar sampel menggunakan metode kromatografi cair kinerja tinggi}

Sampel yang telah dipreparasi diinjeksikan ke dalam instrumen KCKT, dieluasi menggunakan fase gerak (metanol-asetonitril (90:10)), dengan kecepatan alir $1,2 \mathrm{ml} /$ menit, pada temperatur kolom $\pm 25^{\circ} \mathrm{C}$ dan detektor UV-Vis diatur pada panjang gelombang $243 \mathrm{~nm}$ [5].

\subsection{Analis data}

Data yang dianalisis pada penelitian ini antara lain medium difusi dan larutan pengekstrak yang optimum, area under curve (AUC), kurva hubungan antara AUC dengan waktu (t) dan konsentrasi $(\mathrm{C})$ dengan waktu $(\mathrm{t})$ serta kinetika pelepasan sediaan.

\section{Hasil}

\subsection{Profil pelepasan TU dan MPA dalam medium difusi}

Profil pelepasan TU dan MPA dalam medium difusi dapat dilihat pada Gambar 1.

Hasil uji difusi diperoleh pelepasan kadar dari TU dan MPA pada berbagai medium difusi yang dicobakan, pada medium $\mathrm{NaCl}$ diperoleh kadar $\mathrm{TU}=1,744 \mathrm{mg} / \mathrm{ml}$ dan $\mathrm{MPA}=0,1427 \mathrm{mg} / \mathrm{ml}$; pada medium PBS diperoleh kadar $\mathrm{TU}=2,3034$ $\mathrm{mg} / \mathrm{ml}$ dan $\mathrm{MPA}=0,0689 \mathrm{mg} / \mathrm{ml}$; sedangkan pada medium isopropanol-air diperoleh kadar $\mathrm{TU}=2,4494 \mathrm{mg} / \mathrm{ml}$ dan MPA $=0,1010 \mathrm{mg} / \mathrm{ml}$.

\subsection{Penentuan kinetika pelepasan zat aktif}

Kinetika pelepasan zat aktif ditentukan dengan cara menghitung koefisien korelasi Pearson antara dua data sebagai berikut:

a) Orde nol: $t$ (waktu) terhadap C (konsentrasi)

b) Orde satu: t (waktu) terhadap Log C (konsentrasi)

c) Higuchi: $\sqrt{\mathrm{t}}$ (waktu) terhadap $\mathrm{C}$ (konsentrasi) Hasil dari perhitungan koefisien korelasi Pearson dibandingkan antara ketiga kinetika tersebut dan yang terdekat dengan 1 (satu) adalah kinetika yang sebenarnya. Kinetika pelepasan zat aktif dihitung dari medium difusi yang paling optimum yaitu isopropanol-air (1:9).

\subsection{Kinetika pelepasan testosteron undekanoat}

Kinetika pelepasan TU disajikan pada Gambar 2. Dari hasil kinetika diperoleh koefisien korelasi Pearson untuk TU pada kinetika orde nol adalah $r$ =0,9913; pada kinetika orde satu $r=0,8749$; dan pada kinetika Higuchi $r=0,972$.

\subsection{Kinetika pelepasan medroksi progesteron asetat}

Kinetika pelepasan MPA dapat dilihat pada Gambar 3. Dari hasil kinetika diperoleh koefisien korelasi Pearson untuk MPA pada kinetika orde nol adalah $r=0,9777$; pada kinetika orde satu $r$ $=0,7798$; dan pada kinetika Higuchi $r=0,9417$.

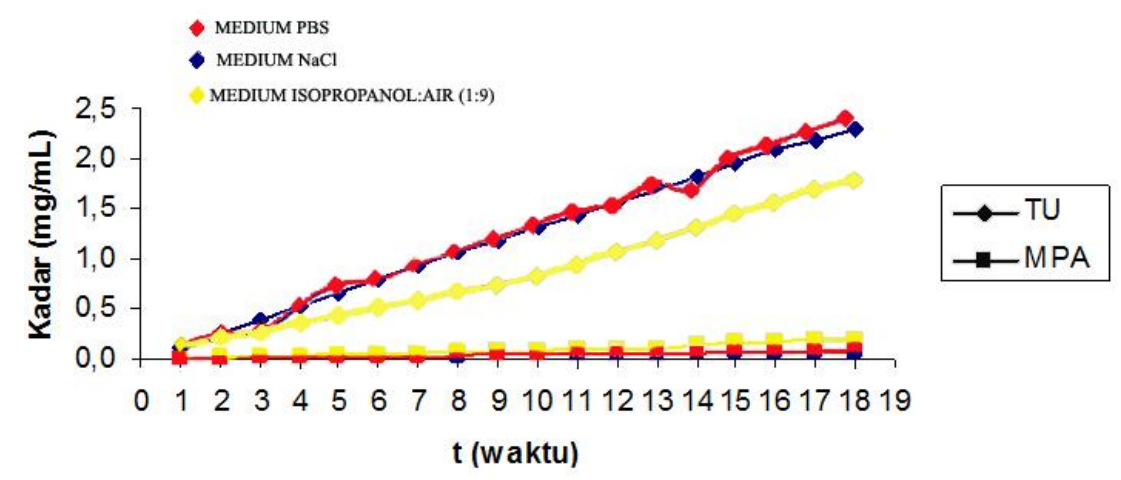

Gambar 1. Profil pelepasan TU dan MPA dalam berbagai medium difusi 


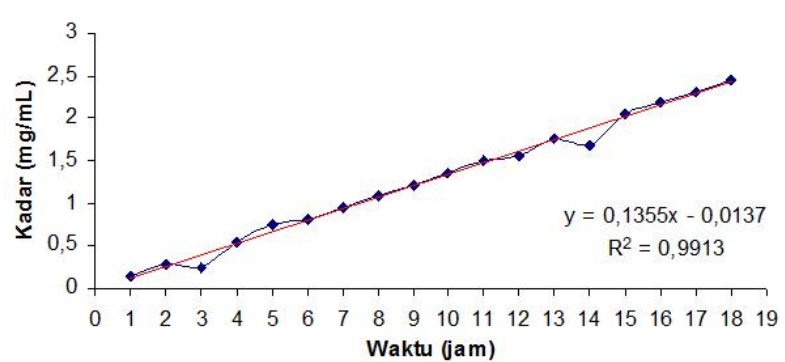

(A)

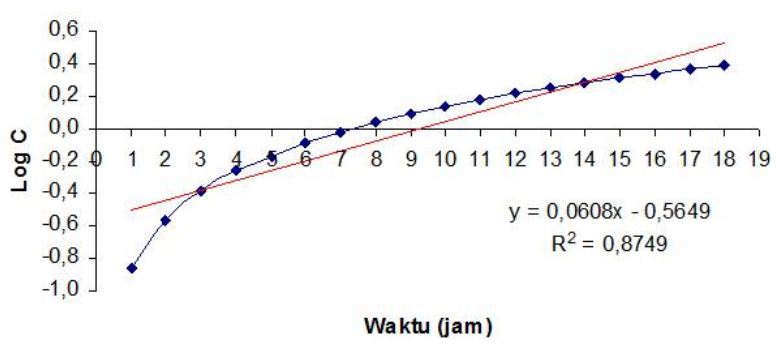

(B)

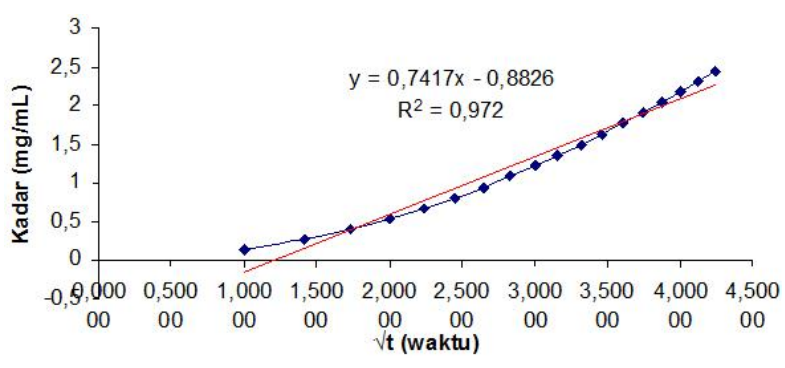

(C)

Gambar 2. Kinetika pelepasan TU dalam medium isopropanol-air (1:9): orde nol (A), orde satu (B) dan Higuchi (C)

\section{Pembahasan}

TU dan MPA bersifat sangat lipofik dengan koefisien partisi masing-masing sebesar 6,91 dan 2,92 . Untuk mengetahui laju difusi dari senyawa yang bersifat lipofilik dapat dimodikasi suatu medium yang dapat meningkatkan kelarutan senyawa tersebut. Dari hasil pengukuran kadar zat aktif yang terpermeasi ke dalam medium dengan menggunakan intrumen KCKT dari ketiga medium di atas diperoleh medium yang paling optimum adalah isopropanol-air (1:9). Hal ini dapat dilihat dari kadar TU dan MPA yang terlarut dalam medium ini merupakan

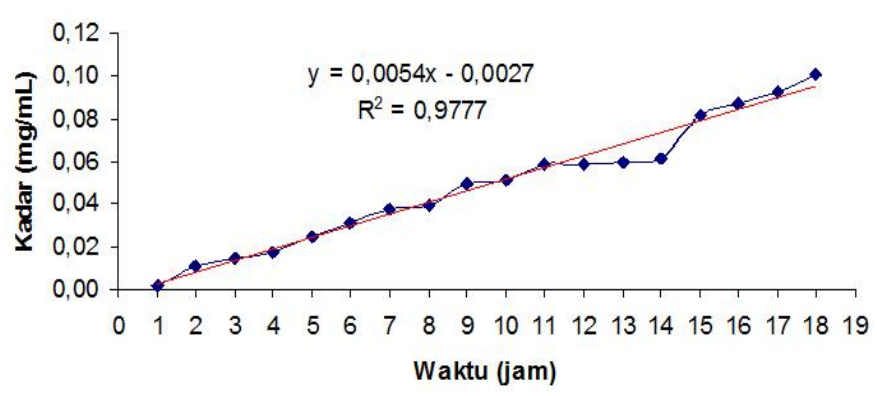

(A)

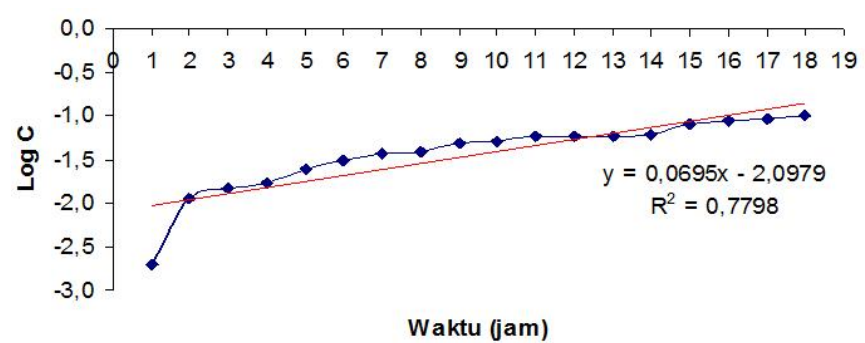

(B)

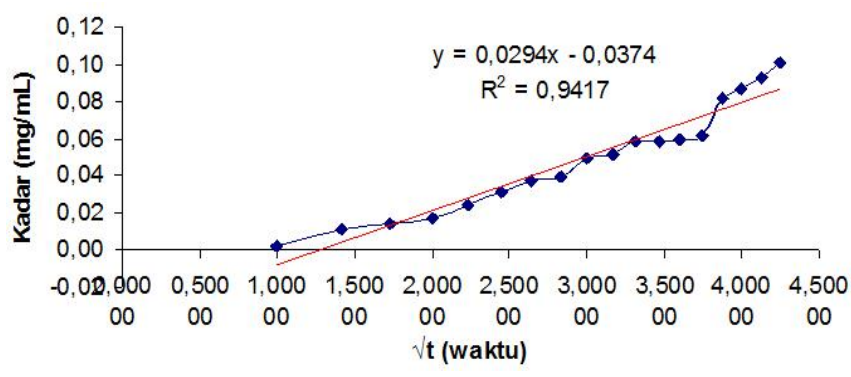

(C)

Gambar 3. Kinetika pelepasan MPA dalam medium isopropanol-air (1:9): orde nol (A), orde satu (B) dan Higuchi (C)

yang paling tinggi dari kedua medium lainnya. Isopropanol merupakan pelarut golongan alkohol yang sangat mudah menguap dan terbakar. Secara struktural isopropanol juga memiliki kemiripan dengan TU dan MPA sehingga lebih mudah pula untuk melarutkan keduanya. Sebagai pelarut, isopropanol mempunyai daya larut yang besar terhadap senyawa-senyawa non polar. Isopropanol juga merupakan pelarut yang tidak terlalu toksik [5]. Dari ketiga medium yang digunakan, isopropanol-air (1:9) merupakan medium yang paling dapat melarutkan TU dan medium $\mathrm{NaCl}$ fisiologis merupakan medium paling baik untuk MPA. Hal ini dapat dilihat dari 
kadar MPA dan TU yang terlarut dalam masingmasing medium merupakan yang paling besar jumlahnya.

Pengujian difusi yang digunakan yaitu Franz Diffusion Cell karena memiliki diameter peletakan membran yang lebih besar dari alat pengujian difusi flow through cell, sehingga luas permukaan membran yang kontak terhadap medium pun lebih besar yang nantinya berpengaruh pada besarnya kadar senyawa yang berdifusi ke dalam medium. Selain itu faktor lain yang mempengaruhi yaitu volume reseptor yang berbeda menghasilkan perbedaan kadar yang terdeteksi pula. Pada flow through cell volume reseptor sebanyak $330 \mathrm{ml}$ sehingga kadar yang terdeteksi semakin kecil, dibandingkan dengan volume reseptor pada Franz Diffusion Cell yaitu $23 \mathrm{ml}$ sehingga kadar yang terdeteksi pun lebih besar. Penelitian ini menggunakan KCKT sehingga dapat mendeteksi kadar senyawa walaupun dalam konsentrasi yang sangat kecil.

Apabila dianalis dari aspek biofarmasetika obat, maka ada beberapa faktor yang mempengaruhi laju pelepasan obat secara intramuskular dengan formulasi yang mengandung minyak seperti pada formula tunggal dan mikroemulsi. Faktor tersebut antara lain: partisi obat dari pembawa minyak terhadap tissue fluid, penyebaran, dan dispersi larutan minyak pada tempat penyuntikan, volume penyuntikan, viskositas formulasi, difusi obat/zat aktif dalam pembawa minyak, fisiologi tempat penyuntikan, dan teknik penyuntikan [6].

Pembuatan sediaan mikroemulsi ini ditujukan untuk memberikan efek depo. Dengan pelepasan yang sedikit-demi sedikit akan mendukung tujuan pembuatan sediaan mikroemulsi tersebut tercapai. Pelepasan obat jangka panjang juga bukan hanya dilihat dari pelepasan zat aktifnya tetapi juga harus bertahap (controlled release) sesuai dengan tujuan yang diharapkan. Untuk mengetahui profil laju difusinya dapat dilihat dari nilai koefisien korelasi ( $r$ ) dari t (waktu) terhadap C (konsentrasi) untuk kinetika pelepasan orde nol mendekati satu.
Dari perhitungan kinetika pelepasan di atas dapat disimpulkan bahwa pelepasan zat aktif sediaan mengikuti kinetika yaitu orde nol yang dilihat dari nilai $r$-nya lebih mendekati 1 untuk kedua zat aktif. Penelitian ini masih jauh dari sempurna, perlu dilakukan suatu modifikasi metode laju difusi yang menggambarkan kondisi yang sebenarnya dalam tubuh untuk pelepasan obat yang diberikan secara intramuskular.

\section{Kesimpulan}

Dari optimasi uji difusi yang dilakukan maka diperoleh kesimpulan bahwa medium difusi yang paling optimum adalah medium isopropanol-air (1:9) dengan kadar TU dan MPA yang diperoleh yaitu 2,4494 mg dan 0,1010 mg, sedangkan substansi/korelasi dengan penggunaan in vivo medium $\mathrm{NaCl}$ dengan kadar TU sebesar 1,7444 mg dan MPA sebesar 0,1427 mg. Kinetika pelepasan sediaan ini mengikuti kinetika pelepasan orde nol.

\section{Daftar pustaka}

1. Behre HM, Abshagen $K$, Oettel $M$, Hübler $D$, Nieschlag E. Intramuscular injection of testosterone undecanoate for the treatment of male hypogonadism: phase I studies. European Journal of Endocrinology, 1999;140(5): 414-9.

2. Gu YQ Jian-sun T, Ding-zhi M, Xing-hai W, Dong Y, Wen-hao T, William JB. Male hormonal contraception: effects of infections of testosterona undecanoate and depot medroxyprogesterone acetate at eight-week intervals in Chinese men. The Journal of Clinical Endocrinology \& Metabolism. 2004;89(5): 2254-62.

3. Moeloek N, Azrifitria, Joshita D, Yurnadi. Formulasi mikroemulsi TU dan MPA serta uji aktivitas farmakokinetik pada tikus jantan galur SD. Hibah SILAB UI. 2010.

4. Martin A, Swarbrick J, Cammarata A. Farmasi fisik: dasar-dasar kimia fisik dalam ilmu farmasetika. Jakarta: UI Press; 1993. 
5. Moeloek N, Azrifitria, Rianto S, Joshita D. Pharmacokinetic profile of TU and MPA delivered in parenteral microemulsion. Proceeding Conference of AASP; 2011.
6. Talegaonkar S, Azeem A, Ahmad FJ, Khar RK, Pathan SA. Microemulsions: a novel approach to enhanced drug delivery. Recent patents on drug delivery \& formulation. 2008;2(3): 238-57. 